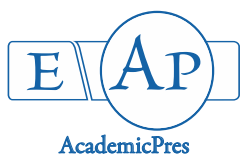

Albert S and Gandhi D (2021)

Notulae Scientia Biologicae

Volume 13, Issue 3, Article number 10807

DOI: $10.15835 /$ nsb13310807

Research Article

\title{
Characterization of lemma and palea in nine different species of Eragrostis (Poaceae)
}

\author{
Susy ALBERT*, Dhara GANDHI
}

The Maharaja Sayajirao University of Baroda, Faculty of Science, Department of Botany, Vadodara 390002, Gujarat, India;drsusyalbert@rediffmail.com ("correspondingauthor);djgandhi21@gmail.com

\begin{abstract}
Eragrostis, the largest genus in tribe Eragrostideae has 36 species in India and with 406 species in the world. The present study investigates the morphological and micromorphological variations of lemma and palea in nine species of the Eragrostis, collected from Panchmahal and Dahod districts of Gujarat. Qualitative and quantitative features of microharis, and epidermal cells in the different regions, apex middle and base of lemma and palae has been observed. Apart from this, undulation patterns also play a key role in species identification. Two major types of undulation pattern $\cap$ and $\Omega$ have been observed in the studied species. The present study concludes that, different types of microhairs, size and shape of epidermal cells and its undulating pattern can be significantly used in delimitation of Eragrostis with the help of all the qualitative and qualitative characteristic features it was possible to prepare a dichotomous key to identify the nine different species of Eragrostis.
\end{abstract}

Keywords: Eragrostis, micromorphology; lemma; palea; undulation

\section{Introduction}

Eragrostis Wolf the largest genus having 406 species (POWO, 2021) belong to subfamily Chlorideae of the tribe Eragrostidae in family Poaceae. These species occur in tropical, subtropical and warm temperate regions throughout the world (Clayton and Renvoize, 1986; Peterson et al., 1993, 2001; Van den Borre and Wasten, 1994). Within in India 36 species (Karthikeyan et al., 1989) and in Gujarat 14 species (Shah, 1978) were recorded. Eragrostis the species limits are often overlapping and few agrostologists have attempted to work out on suitable phylogenetic scheme. Based on spikelet disarticulation at maturity, Clayton et al. (1974) and Clayton and Renvoize (1986) have arrived at a "first approximation to natural groups" and have presented a key to sections Psilantha, Eragrostis, Lappula and Platystacha. Members of Eragrostis generally are characterized by paniculate inflorescences, multifloreted spikelets, glabrous, three nerved lemmas and ciliate ligules (Zeid et al., 2011).

The best combination of characters used to discriminate this genus from other Eragrostideae is disarticulation of the lemmas and palea occurring separately, longitudinally bowed out paleas with ciliolate keels and 3-nerved, unawned lemmas.

Micromorphological characters of different parts of grass are of great value in taxonomic studies of family Poaceae, especially part like leaf (Prant, 1932, 1936; Metcalfe, 1960; Ellis, 1979; Baum et al., 1987;

Received: 22 Aug 2020. Received in revised form: 14 Aug 2021. Accepted: 22 Aug 2021. Published online: 02 Sep 2021.

From Volume 13, Issue 1, 2021, Notulae Scientia Biologicae journal uses article numbers in place of the traditional method of continuous pagination through the volume. The journal will continue to appear quarterly, as before, with four annual numbers. 
Amarasinghe and Waston, 1990). Apart from leaf, characters of floral bracts including lemma and palea are also very important to know the phylogeny and evolutionary relationship between taxa. Micromorphological features useful for the identification and characterization of tribes and subfamilies, for example absence of micro hairs is characteristic in Pooideae (Clayton and Renvoize, 1986). Micro and macro characters have taxonomic significance within genera, as in the case of micro hairs in Eragrostis (Amarasinghe and Waston, 1990), being especially useful for the characterization of the larger groups, particularly sub families and tribes. The present study aims to characterize Eragrostis at the species level, based on characters of micromorphological characteristic features of lemma and palea.

\section{Materials and Methods}

Total nine species of Eragrostis were collected from the grasslands of Baria and Godhra forest division of Panchmahal districts. 20-25 individuals of species were gathered and identified Lemma and palea from the lowest floret in the spikelet were carefully separated, washed with distilled water to remove any dust particles adhering to it and used for observations from the apical, middle and basal portions of each part. Observations were carried out first with a stereo microscope and then under light microscope. Terms described by Ellis (1979) was followed for description of micromorphological features. The different spikelets and its parts were photographed with Leica DME microscope.

\section{Results and Discussion}

\section{Lemma and palea of Eragrostis}

Length of lemma is more than palea in all studied species, except Eragrostis japonica and Eragrostis tenella. A variation in the number of veins on the surface of glumes have been distinctly noted. In Eragrostis pilosa the surface of glumes are smooth with an absence of veins while in all the other species a single the centre of the lemma and palea and in Eragrostis ciliaris the number of veins vary form 1 to 3.

Lemma of Eragrostis tenella shows glabrous surface while others with scrabous surface. Apex of lemma obtuse in all the species, except Eragrostis nutans and Eragtostis unioloides with acute apex. Shape of upper and lower glumes ovate except Eragrostis ciliaris with lanceolate glumes. All the Eragrostisspecies had an acute apex in both glumes. Lemma and palea of nine species showsn in Figure 1.

Microhairs

Microhairs in grasses are characteristically bicellular. It is commonly found on the leaves but also occur on the other parts like lemma, palea and lodicules (Tateokaet al., 1959; Metcalfe, 1960; Tateoka and Kawano, 1967; Takeota, 1967; Terrel and Wergin, 1981; Scholz, 1985). Their presence and absence are widely used as a taxonomic character (Prat, 1936; Metcalfe, 1960; Waston et al., 1985). Morphologically, microhairs are generally classified into three major types (Tateokaet al., 1959; Metcalfe, 1960; Johenston and Waston, 1979) viz., the 'chlorideae type' with relatively short, broad (approaching hemi spherical) and thick-walled cap cells; the 'panicoid type' with relatively long, narrow and thin walled, elongated cap cells; the 'enneapogon type' with very long basal cells and ovoid cap cells.

Unicellular or bicellular trichomes were prominently seen on glumes. Nerve hairs a common feature noted in Eragrostis is characterized by being completely covered by the hairs directed towards the apex. Significant variation has been observed in the density of the hairs. Variations were also found in the apex, basal regions, nerve and marginal hairs.

Characteristic features and terminology used in the present study are as per terminology of the grass inflorescence morphology in Grassbase (Clayton et al., 2006), Ausgrass (Simon and Alfonso, 2011) and Grass 
genera of the World (Watson and Dallwits, 1992). A total of 45 characters were assessed for variability (12 for grass inflorescence and 33 for lemma micromophology). Characteristic terminology of lemma micromorphology has been followed as per Ellis (1979).

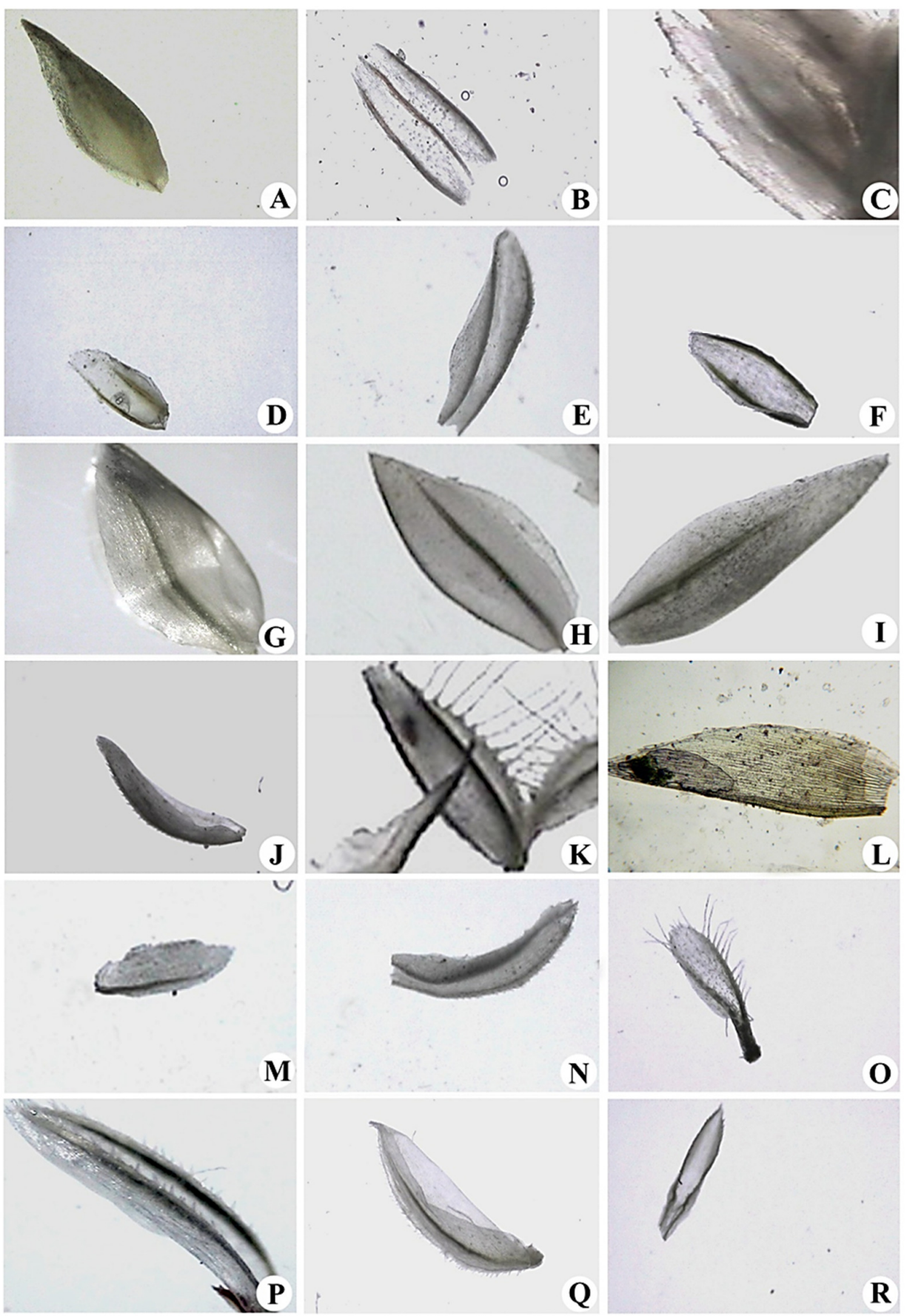

Figure 1. Lemma and palea in nine different species of Eragrostis

A-I: Lemma in different species of Eragrostis; A: Eragrostis cilianensis; B: Eragrostis ciliaris; C: Eragrostis japonica; D: Eragrostis nutans; E: Eragrostis Pilosa; F: Eragrostis tenella; G: Eragrostis tremula; H: Eragrostis unioloides; I: Eragrostis viscosa; J-R: Lemma in different species of Eragrostis; J: Eragrostis cilianensis; K: Eragrostis ciliaris; L: Eragrostis japonica; M: Eragrostis nutans; N: Eragrostis Pilosa; O: Eragrostis tenella; P: Eragrostis tremula; Q: Eragrostis unioloides; R: Eragrostis viscosa 


\section{Micromorphological description of lemma and palea in Eragrostis \\ Microhairs}

\section{Eragrostis cilianenesis}

Lemma: Nerves are smooth. At apex region there are 2-3 nerve hairs are present with less density. Multicellular trichomes are present on the surface with less density (Figure $3 \mathrm{~A}, \mathrm{~B}, \mathrm{C}$ ).

Palea: On nerve spiny, thick walled, rough, unicellular trichomes with broad base. Multicellular trichomes are small compared to one long cell of palea and base is rounded (Figure $2 \mathrm{~A}$ ).

\section{Eragrostis ciliaris}

Lemma: Nerve hairs are not long as of palea. They are unicellular, narrow with broad base, pointed tip, direction towards apex of the lemma, bulbous hairs found at the base region (Figure $2 \mathrm{D}$ ). At margin of the lemma there are many unicellular hairs are present which have pointed tip and broad base. Density is more (Figure 2 B, C).

Palea: Broad, long, unicellular hairs rigidly spreading at maturity. Spiny hairs with bulbous base thick walled vary in length arise from the nerve region, long hairs arranged loosely, direction towards the apex with more density (Figure 2 D, E). The short unicellular hairs found on the all over surface, tips are pointed, narrow and long and thin walled. The base is more rounded, density is more at the apex region (Figure $2 \mathrm{~F}$ ).

\section{Eragrostis japonica}

Lemma: Unicellular, small, thin-walled margin hairs and direction towards apex region. Bulbous hairs are found on the surface, density is less. Apex hairs found arranged parallel (Figure 3 E, F, G).

Palea: Spiny, thick walled, rough, unicellular trichomes are present on nerves directing towards the apex of palea. But density is very less, base broad arising from the nerve region. Multicellular bulbous hairs found on the surface with less density (Figure 2 G, H, I).

\section{Eragrostis nutans}

Lemma: Unicellular hairs found on the apex region, bulbous hairs (Figure $3 \mathrm{I}$ ) are present on the surface, density is less.

Palea: Thick walled, unicellular trichomes are present on nerves of palea. Multicellular bulbous hairs found on the surface with less density (Figure $2 \mathrm{~J}, \mathrm{~K}$ ).

\section{Eragrostis pilosa}

Lemma: Spiny, thick walled, rough, unicellular nerve hairs are present on nerves directing towards the apex of palea. Base broad arises from the nerve region (Figure $2 \mathrm{~L}$ ).

Palea: At apex region, 2-3 hairs, thick walled, unicellular, pointed tip, spiny nerve hairs are present, density more, arise from the nerve region, direction towards the apex, having broad base. Bulbous, multicellular hairs are present at the base region. Some globular trichomes with globular tip are also present but density is very less.

\section{Eragrostis tenella}

Lemma: Long ciliate, broad, unicellular spiny prickles with bulbous base thick walled vary in length arise from the nerve region. The short unicellular, narrow and long, thin walled, pointed broad tip hairs found on the all over the surface. The base is more rounded and density is more at apex region (Figure $2 \mathrm{M}, \mathrm{N}$ ).

Palea: Nerve hairs are long, ciliate along the keels, rigidly spreading at maturity, very broad, unicellular, spiny hairs with bulbous base, thick walled and vary in length (Figure $2 \mathrm{O}, \mathrm{Q}$ ). Density of long hairs is more, arranged loosely and direction towards the apex is not necessary. The short unicellular prickles found on the all over the surface, broad tip which is pointed, narrow, long and thin walled (Figure $2 \mathrm{P}$ ). The base is more rounded, density is more found more at the apex region. Multicellular bulbous hairs are also present at the basal region, the cells have rounded cap and long middle region the base is bulbous scattered at the basal region and density is less (Figure $3 \mathrm{M}, \mathrm{N}$ ). 

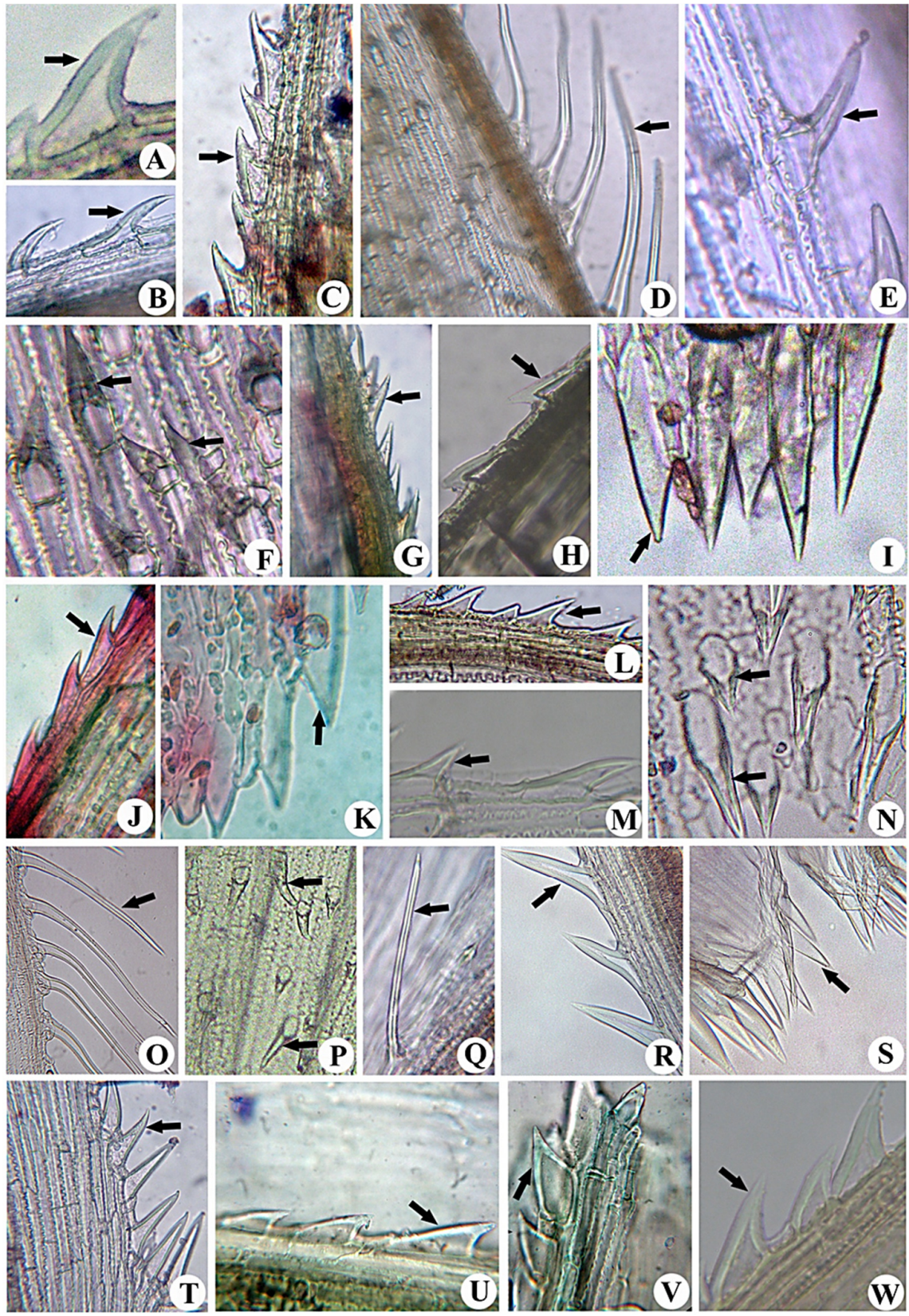

Figure 2. A-W: Hairs macro on lemma and palea of nine different species of Eragrostis

A: Unicellular, pointed nerve hairs of Eragrostis cilianensis; B: Unicellular, pointed hairs present on middle region of Eragrostis ciliaris; C: Unicellular, pointed nerve hairs of Eragrostis ciliaris; D: Unicellular, long pointed nerve hairs of Eragrostis ciliaris; E: Unicellular, pointed surface hairs of Eragrostis ciliaris; F: Prickles of Eragrostis ciliaris; G \& H: Unicellular, long pointed nerve hairs of Eragrostis japonica; I: Unicellular, long hairs present on apex of Eragrostis japonica ; J: Unicellular, pointed nerve hairs of Eragrostis nutans; K: Unicellular, pointed hairs present on apex of Eragrostis nutans; L: Unicellular, pointed nerve hairs of Eragrostis Pilosa; M: Unicellular, pointed nerve hairs of Eragrostis tenella; N: Unicellular, pointed prickles of Eragrostis tenella; O: Unicellular, pointed long nerve hairs of Eragrostis tenella; P: Unicellular, pointed hairs with bulbous base present on surface of Eragrostis tenella; Q: Unicellular, pointed prickles of Eragrostis tenella; R: Unicellular, pointed nerve hairs of Eragrostis tremula; S: Unicellular, pointed hairs present on apex of Eragrostis tremula; T: Unicellular, pointed nerve hairs of Eragrostis unioloides; U: Prickles of Eragrostis unioloides; V: Unicellular, pointed broad base hairs present on apex of Eragrostis unioloides; W: Unicellular, pointed nerve hairs of Eragrostis viscosa 


\section{Eragrostis tremula}

Lemma: Bulbous hairs are found on the surface with less density. At nerve hairs are absent but 1-2 are found at apex region.

Palea: Nerve hairs are long, narrow, base not much broad, unicellular, pointed tip, direction towards apex of the palea, thin walled, smooth surface. Bulbous hairs found at the base region. At the apex region, hairs are found in cluster and are long, narrow with smooth margin and thin wall arise from the tip of the palea (Figure 2 R, S).

\section{Eragrostis unioloides}

Lemma: Unicellular nerve hairs are thin walled, bulbous base direction towards the apex, at the apex hairs are not found. Bulbous hairs are found at the base region.

Palea: Marginal prickles are unicellular, very thin walled, bulbous base, direction towards the apex side (Figure $2 \mathrm{U}$ ). Smooth, small, minute, multicellular surface hairs are scattered at the base region (Figure $2 \mathrm{~T}$ ).

\section{Eragrostis viscosa}

Lemma: 1-2 nerve hairs are found at the apex region which are small pointed and thin walled.

Palea: Nerve hairs are thick walled, rough, broad base, pointed tip, unicellular, directing towards the apex. Density is more. They arranged compactly on the margin. Few small multicellular bulbous hairs are present at the base region (Figure $3 \mathrm{~T}$ ).

Epidermal cells

Micromorphometric features have been represented in Table 1 and 2. Cells present on the surface of lemma are smaller than palea except lemma of Eragrostis tremula had more length than the palea.

\section{Eragrostis cilianenesis}

Lemma:

Apex: Cells are long and narrow. Long cells interrupted by short cells. Undulated wall is loosely arranged. The epidermal long cell walls wavy undulated. The undulations rounded. Most commonly observed straight wall between two cells. Short cell density more (Figure $4 \mathrm{~A}$ ).

Middle: The cells are long. Undulation is wavy, loosely arranged. The epidermal cells are interrupted by the short cells. The undulation is very loosely arranged and irregular, no particular shape is observed (Figure 4 B). 4C).

Base: Cells are long and broad. Short cell density is more. Undulation wavy and loosely arranged (Figure

Palea:

Apex: Cells are long and narrow. Undulated wall is compactly arranged. The epidermal long cell walls are $\mathrm{\cap}$-undulated. The undulations rounded, wider towards the apex and slightly narrower at the base. Most commonly observed oblique wall between two cells. Sometimes also seen straight wall too. Various undulation patterns are observed in this region. Short cells are less in number and density is very less (Figure $5 \mathrm{~J}$ ).

Middle: Cells are long, narrow. Undulations are loosely arranged. Short cells are very less and density is less. The wall between two cells is either oblique or straight. The undulation is wavy, and base is also broad (Figure $4 \mathrm{~K}$ ).

Base: Cells are long, broad and Interrupted by short cells. The density of short cells is less. The undulation wall is wavy. Undulation is loosely arranged, and the transverse wall is straight (Figure $4 \mathrm{~L}$ ). 

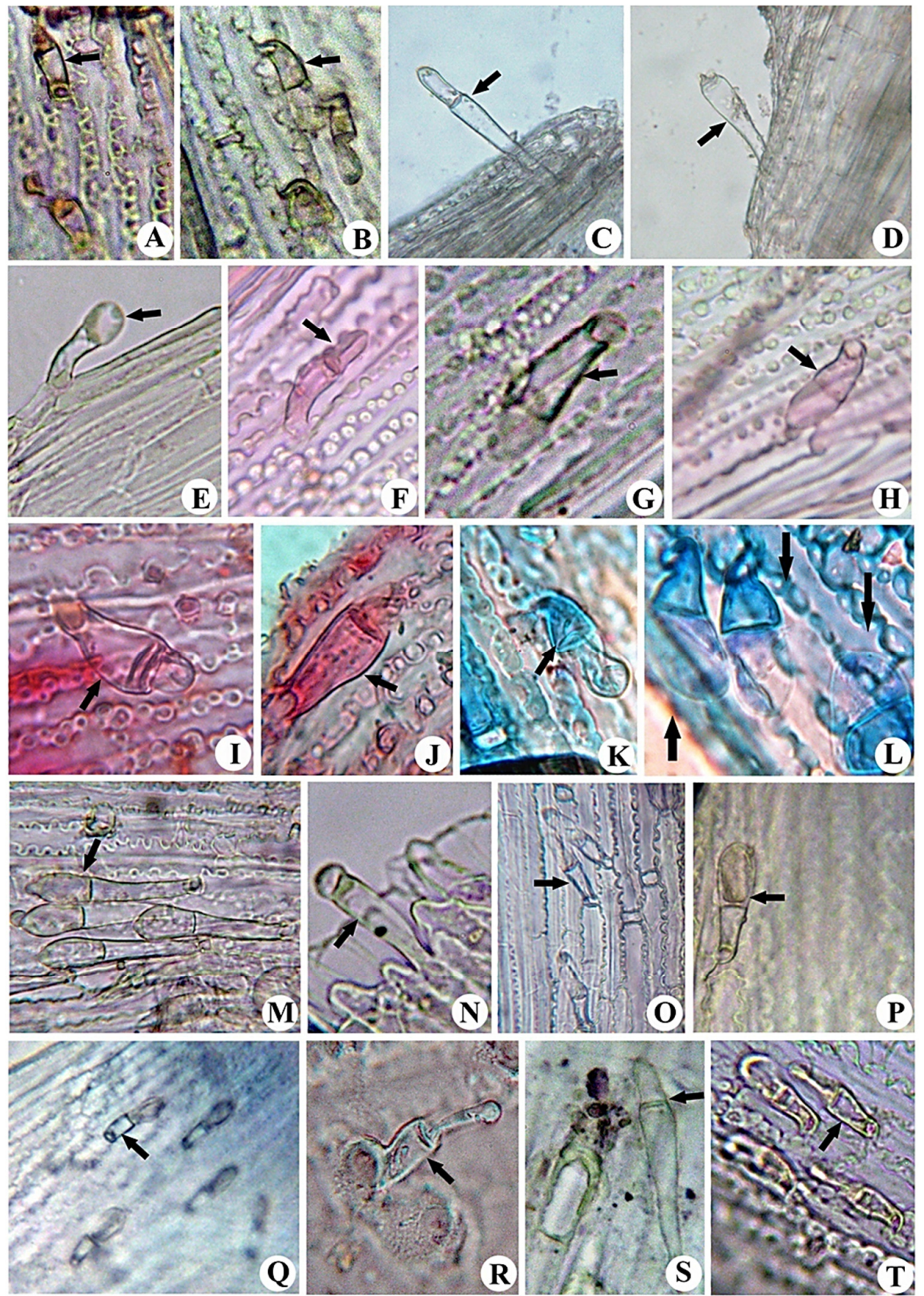

Figure 3. Trichomes of lemma and palea in nine different species of Eragrostis

A: Multicellular, glandular trichome with capitate head of Eragrostis cilianensis; B: Multicellular, glandular trichome of Eragrostis cilianensis; C: Multicellular trichome of Eragrostis cilianensis; D: Multicellular trichome with globular head of Eragrostis ciliaris; E, F\& G: Multicellular, glandular trichome Eragrostis japonica; H: Multicellular, glandular trichome of Eragrostis nutans; I: Multicellular trichome with capitate head of Eragrostis nutans; J: Multicellular trichome with globular head of Eragrostis nutans; K: Multicellular, glandular trichome with capitate head of Eragrostis Pilosa; L: Multicellular, glandular trichome with bulbous head of Eragrostis Pilosa; M: Multicellular, glandular trichome with capitate head of Eragrostis tenella; N: Multicellular, glandular trichome of Eragrostis tenella; O: Multicellular trichome with globular head of Eragrostis tremula; P \& Q: Multicellular, glandular trichome with 
capitate head of Eragrostis unioloides; R: Multicellular trichome with globular head of Eragrostis unioloides; S: Multicellular trichome of Eragrostis unioloides; T: Multicellular, glandular trichome of Eragrostis viscosa
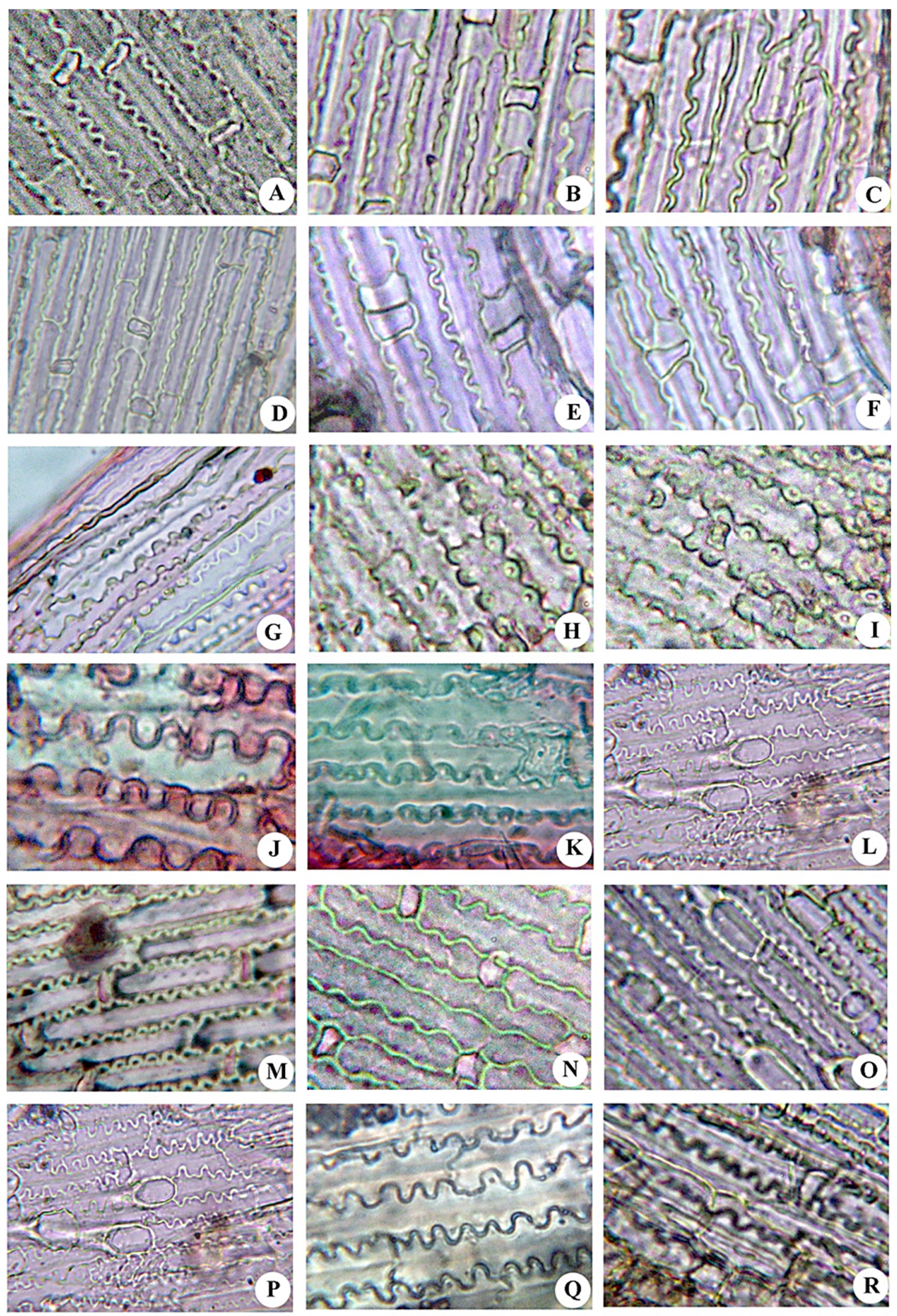

Figure 4. Cells of Lemma in different species of Eragrostis 
A-I: Variations in cells of Lemma in different species of Eragrostis; A-C: Eragrostis cilianensis; D-F: Eragrostisciliaris; G-I: Eragrostis japonica; J-L: Eragrostis nutans; M-O: Eragrostis Pilosa; P-R: Eragrostis tenella; A, D, G, J, M, P: Cells of apex region; $\mathrm{B}, \mathrm{E}, \mathrm{H}, \mathrm{K}, \mathrm{N}$, Q: Cells of middle region; $\mathrm{C}, \mathrm{F}, \mathrm{I}, \mathrm{L}, \mathrm{O}, \mathrm{R}$ : Cells of basal region

\section{Eragrostis ciliaris}

\section{Lemma:}

Apex: The cells are long and interrupted by the short cells with slightly undulating wall (Figure $4 \mathrm{D}$ ).

Middle: Cells are very narrow and long. Long cells are interrupted by short cells. The undulation is irregular, wavy, loosely arranged (Figure $4 \mathrm{E}$ ).

Base: The cells are long and broad. Undulation is wavy and irregular. Short cells are present more (Figure $4 \mathrm{~F})$.

Palea:

Apex: Cells are not much ling and interrupted by short cells. Undulated wall is loosely arranged. The epidermal long cell walls are sinusoidal-undulated. The undulations rounded, narrower towards the apex and wider at the base. Both oblique and straight walls are observed between two cells. Short cells density is more (Figure $5 \mathrm{M}$ ).

Middle: Cells are long and wavy. Undulation is irregular, loosely arranged, short cells are very less. The wall between two cells is mostly oblique type and which also shows undulation (Figure $5 \mathrm{~N}$ ).

Base: The cells are long and narrow. The transverse wall is straight. The undulation is wavy and loosely arranged (Figure $5 \mathrm{O}$ ).

\section{Eragrostis japonica}

\section{Lemma:}

Apex: The cells are long with loosely arranged, irregular undulation and narrow tip followed by the broader region (Figure $4 \mathrm{G}$ ).

Middle: The undulation has specific $\Omega$ shaped. Long, narrower cells with straight transverse wall (Figure $4 \mathrm{H}$ ).

Base: The cells show $\Omega$ shaped undulation. The transverse wall is oblique (Figure 4 I).

Palea:

Apex: Undulated wall is compactly arranged. Cell walls are $\cap$-undulated. The undulations rounded, wider towards the apex and slightly narrower at the base. Most observed oblique wall between two cells (Figure $5 \mathrm{P})$.

Middle: Undulation is very compactly arranged. The apex is slightly broad and rounded followed by base which is broader. The cells are short in length and broad (Figure $5 \mathrm{Q}$ ).

Base: The undulation is $\Omega$ shaped. The cells are short in length and broaden in width. Short cell density is very less. Undulation is compactly arranged (Figure $5 \mathrm{R}$ ).

\section{Eragrostis nutans}

Lemma:

Apex: Long epidermal cells with compact undulation wall with $\cap$-undulation. The undulations rounded, wider towards the apex and slightly narrower at the base. Most observed oblique wall between two cells but sometimes straight also (Figure $4 \mathrm{~J}$ ).

Middle: The undulation has $\Omega$ shaped. The cells are very long, narrow. Short cells are very less (Figure $4 \mathrm{~K})$.

Base: The undulation is very compactly arranged and highly wavy. Cells are long, narrow. Short cells are less (Figure 4L).

Palea:

Apex: The epidermal long cell walls are $\cap$-undulated. The undulations rounded, wider towards the apex and slightly narrower at the base (Figure $6 \mathrm{~A}$ ). 
Middle: Undulation is compactly arranged. Cells are narrower and long. Short cells are very less, very compactly arranged cells which are not vary in length (Figure $6 \mathrm{~B}$ ).

Base: The undulation is $\Omega$ shaped. The cells are short in length and broad. The apex of undulation is less broad (Figure $6 \mathrm{C}$ ).

\section{Eragrostis pilosa}

Lemma:

Apex: Undulation is compactly arranged. Mostly straight wall are found between the two cells but sometimes oblique also (Figure $4 \mathrm{M}$ ).

Middle: Epidermal cells are very thin walled, long and narrow; interrupted by short, rounded cells (Figure $4 \mathrm{~N}$ ).

Base: The epidermal cells are broad and long. Undulation compactly arranged. The apex is narrow and base is broad (Figure $4 \mathrm{O}$ ).

Palea:

Apex: Cells are long and wide. Undulated wall is compactly arranged. The epidermal long cell walls are $\cap$-undulated. The undulations rounded, wider towards the apex and broad at the base. Most commonly observed oblique wall between two cells. Short cells density less (Figure $6 \mathrm{D}$ ).

Middle: The undulation is $\Omega$ shaped. Commonly found. The transverse wall between two cells are different either straight or oblique. The transverse wall also shows undulation (Figure $6 \mathrm{E}$ ).

Base: The cells are distinctly seen. The undulation wall is straight. The transverse walls between two cells are oblique as well as straight (Figure 6 F).

\section{Eragrostis tenella}

Lemma:

Apex: The cells are loosely arranged. Undulation is irregular trichomes interrupt the long cells. Almost straight wall if found between the two cells. Undulation has narrow apex and broader base. Various undulations are seen (Figure $4 \mathrm{P}$ ).

Middle: Cells are short, interrupted by unicellular hairs. The undulated walls are not so much coiled. They are irregular and wavy. Cells are long and narrow. The transverse wall is mostly straight and undulated. Cells are very compactly arranged (Figure $4 \mathrm{Q}$ ).

Base: The cells are long and irregular undulation. Large number of short cells are present (Figure $4 \mathrm{R}$ ).

Palea:

Apex: The epidermal long cell walls are irregularly undulated, narrower at the apex and broad at the base. Straight wall observed between two cells. Short cells are observed between long cells (Figure $6 \mathrm{G}$ ).

Middle: Undulation is wavy, irregular type. Cells are long, narrow and short cells are present (Figure 6 $\mathrm{H})$.

Base: The epidermal cells are interrupted by short cells. The cells are long and broad. The transverse walls are both straight as well as oblique. The undulation is very loosely arranged (Figure $6 \mathrm{I}$ ).

\section{Eragrostis tremula}

Lemma:

Apex: Cells are long and much wider. Undulated wall is loosely arranged, very thick wall is present. Short cells are more in number, more density (Figure $5 \mathrm{~A}$ ).

Middle: The undulated wall is very thick, interrupted by small, short cells. The cells are broad and the undulation is compactly arranged. The undulation in apex region the narrower followed by broader region (Figure $5 \mathrm{~B}$ ).

Base: Cells are long and much narrower. Undulated wall is loosely arranged. Short cells are less in number (Figure 5 C). 
Palea:

Apex: Cells are long and much wider. Undulated wall is loosely arranged. The epidermal long cell walls are irregularly undulated. The undulations narrower followed by wider region towards the base and further wider at the base. Oblique walls between two cells. Various undulation patterns are observed in this region (Figure $6 \mathrm{~J}$ ).

Middle: Undulation is very in shapes. Irregular narrow undulation at apex followed by broader region. Cells are broad, short cells are less (Figure $6 \mathrm{~K}$ ).

Base: Cells are long and much wider. Undulated wall is compactly arranged and very thin. Undulation is $\Omega$ shaped which is frequently observed. The transverse wall is almost straight and does not have undulation. Short cells are more in number (Figure $6 \mathrm{~L}$ ).

\section{Eragrostis unioloides}

Lemma:

Apex: Cells are short and narrow. The end walls of the epidermal cells are folded. Undulated wall is wavy. Most commonly observed straight wall between two cells. Short cells density vey less (Figure 5 D).

Middle: The cells show the folded margin at the apex region. This can be a unique feature. The undulation is loosely arranged and having narrower shape at the apex region and broaden towards the basal region. Cells are short, long narrower (Figure $5 \mathrm{E}$ ).

Base: Cells are short and narrow. The end walls of the epidermal cells are folded. Undulated wall is loosely arranged. The undulation is wavy type. Presence of straight wall between two cells. Short cells are less in number (Figure $5 \mathrm{~F}$ ).

\section{Palea:}

Apex: Cells are long and much wider. Undulated wall is loosely arranged. The epidermal long cell walls are irregularly undulated. The undulations narrower, followed by wider region towards the base and further wider at the base. Oblique walls between two cells. Various undulation patterns are observed in this region. Short cells are less in number, density is very less (Figure $6 \mathrm{M}$ ).

Middle: Cells are various in undulations. Undulation apex sometimes narrow and broad base (Figure $6 \mathrm{~N}$ ).

Base: Cells are short and broad. The end walls of the epidermal cells are folded but very less seen. Undulated wall is loosely arranged. The undulation is wavy type. Most commonly observed straight wall between two cells. Short cell density is very less (Figure 6 O).

\section{Eragrostis viscosa}

\section{Lemma:}

Apex: Cells are narrow, long, undulation not compactly folded. Wavy types of undulation present. Short cells are present between the cells (Figure $5 \mathrm{G}$ ).

Middle: The undulation is compactly arranged. The cells are $\Omega$ shaped. The undulation is very compactly. The apex is slightly narrow and towards the base is broader. The epidermal cells are long and broad. Undulation broader at the apex and broader at the base (Figure $5 \mathrm{H}$ ).

Base: The undulation wall is wavy and loosely arranged. Short cells are more (Figure 5 I).

Palea:

Apex: Cells are long and narrow. Undulated wall is compactly arranged. The epidermal long cell walls are $\cap$-undulated. The undulations rounded, wider towards the apex and slightly narrower at the base. Most commonly observed oblique wall between two cells. Sometimes also seen straight wall too. Various undulation patterns are observed in this region. Short cells are less in number, density is very less (Figure $6 \mathrm{P}$ ).

Middle: The cells are compactly arranged. The undulation is $\Omega$ shaped, broader at the apex and at the base (Figure 6 Q).

Base: The cells are highly undulated and having $\Omega$ shaped undulation. The cells are very long and narrow (Figure 6 R). 

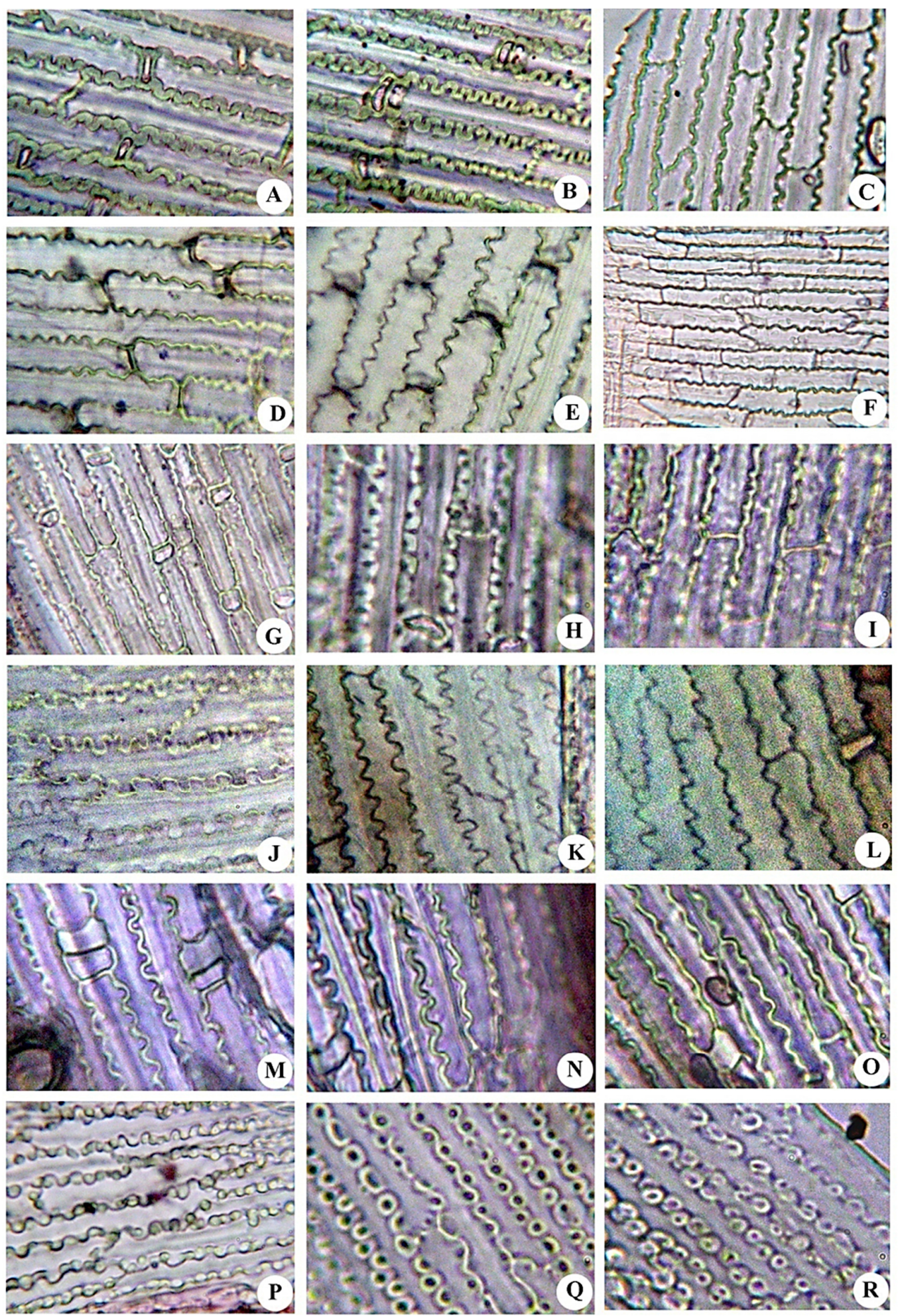

Figure 5. Cells of Lemma and Palea in different species of Eragrostis

A-I: Variations in cells of Lemma in different species of Eragrostis; J-R: Variations in cells of Palea in different species of Eragrostis; A-C: Eragrostis tremula; D-F: Eragrostis unioloides; G-I: Eragrostis viscosa; J-L: Eragrostis cilianensis; M-O: Eragrostis ciliaris; P-R: Eragrostis japonica; A, D, G, J, M, P: Cells of apex region; B, E, H, K, N, Q: Cells of middle region; C, F, I, L, O, R: Cells of basal region 

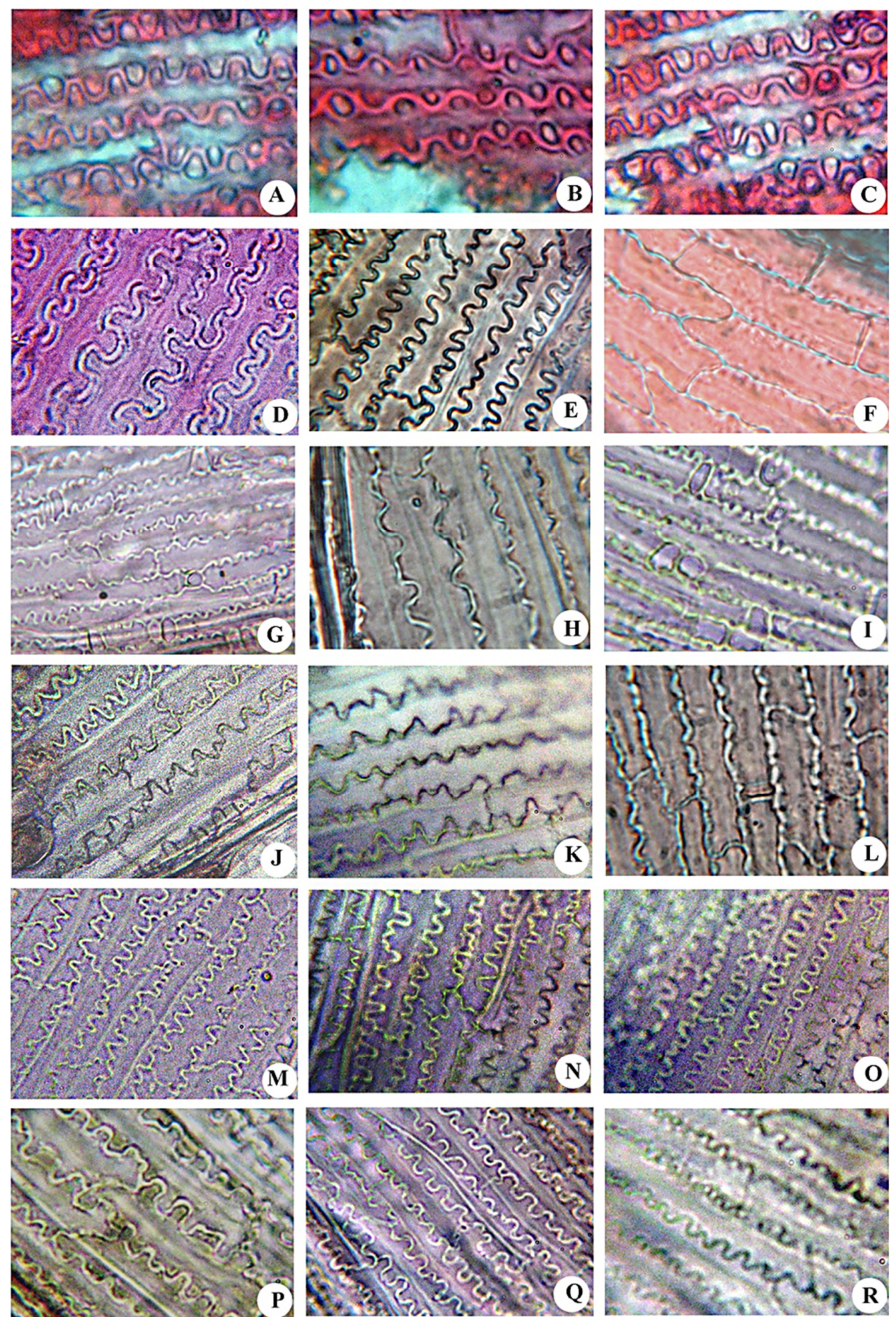

Figure 6. Cells of Palea in different species of Eragrostis

A-I: Variations in cells of Lemma in different species of Eragrostis; A-C: Eragrostis nutans; D-F: Eragrostis Pilosa; GI: Eragrostis tenella; J-L: Eragrostis tremula; M-O: Eragrostis unioloides; P-R: Eragrostis viscosa; A, D, G, J, M, P: Cells of apex region; B, E, H, K, N, Q: Cells of middle region; C, F, I, L, O, R: Cells of basal region 

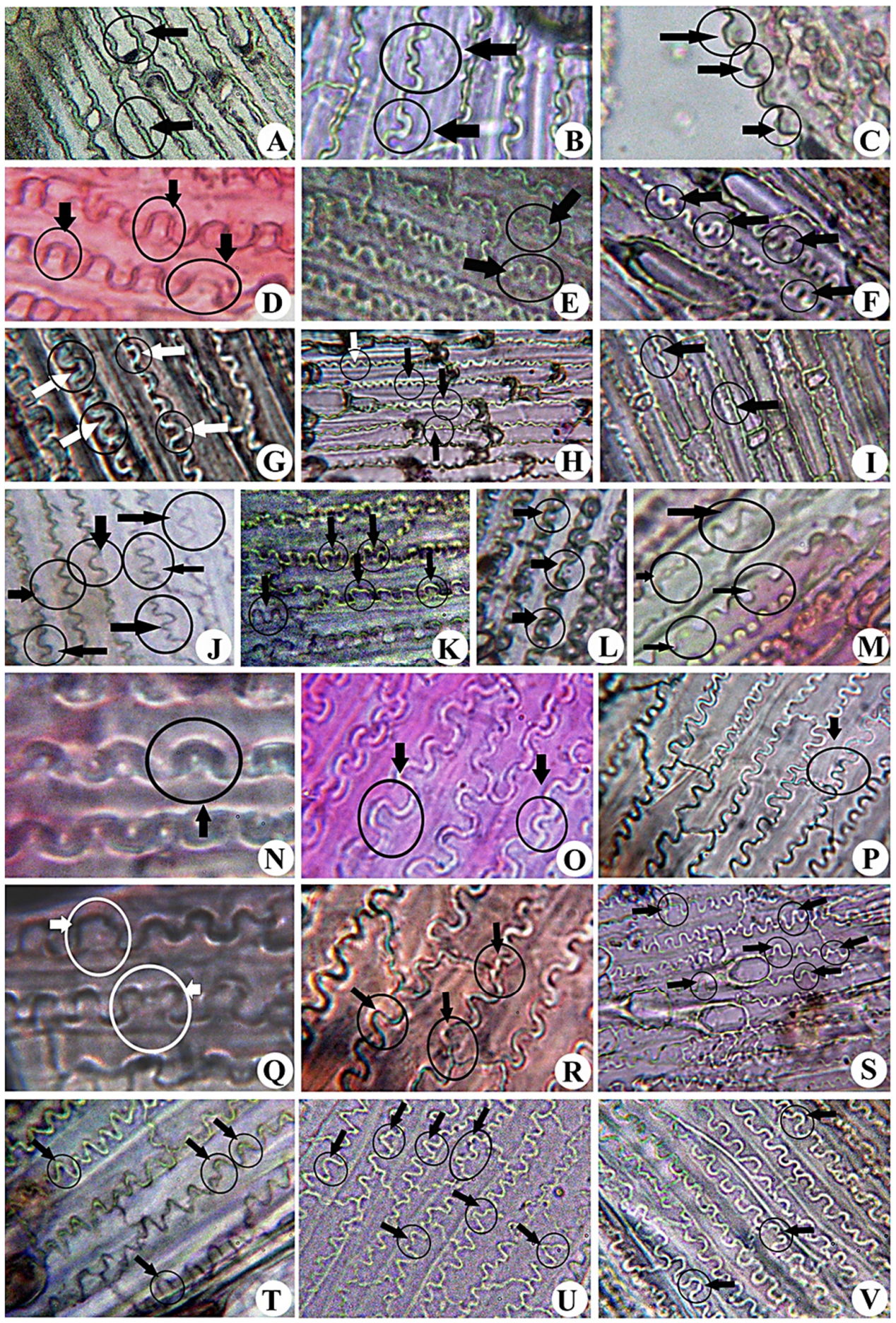

Figure 7. Undulated patterns of epidermal long cells of Lemma and Palea in nine different species of Eragrostis

A-I: Undulated patterns of lemma; A: Eragrostis cilianensis; B: Eragrostis ciliaris; C: Eragrostis japonica; D: Eragrostis nutans; E: Eragrostis Pilosa; F: Eragrostis tenella; G: Eragrostis tremula; H: Eragrostis unioloides; I: Eragrostis viscosa; J-V: Undulated patterns of palea; J: Eragrostis cilianensis; K: Eragrostis ciliaris; L \& M: Eragrostis japonica; N: Eragrostis nutans; O- R: Eragrostis Pilosa; S: Eragrostis tenella; T: Eragrostis tremula; U: Eragrostis unioloides; V: Eragrostis viscosa 
Table 1. Comparison of micromorphological characters of Lemma

\begin{tabular}{|l|c|c|c|c|c|c|c|c|c|c|}
\hline \multirow{2}{*}{$\begin{array}{c}\text { Name of } \\
\text { species }\end{array}$} & \multicolumn{2}{|c|}{ Apex cells $(\mu \mathrm{m})$} & \multicolumn{2}{c|}{ Middle cells $(\mu \mathrm{m})$} & \multicolumn{2}{c|}{ Basal cells $(\mu \mathrm{m})$} & \multicolumn{2}{c|}{ Hairs $(\mu \mathrm{m})$} & \multicolumn{2}{c|}{ Lemma $(\mu \mathrm{m})$} \\
\cline { 2 - 12 } & Length & Width & Length & Width & Length & Width & Length & Width & Length & Width \\
\hline Eragrostis & $48.25 \pm$ & $6.0 \pm$ & $48.5 \pm$ & $7.25 \pm$ & $43.25 \pm$ & $6.75 \pm$ & $13.25 \pm$ & $6.5 \pm$ & $1143.0 \pm$ & $739.8 \pm$ \\
cilianensis & 1.59 & 4.02 & 1.5 & 0.2 & 5.97 & 0.09 & 3.11 & 0.2 & 24.09 & 15.75 \\
\hline Eragrostis & $44.7 \pm$ & $7.25 \pm$ & $42.75 \pm$ & $5.75 \pm$ & $54.25 \pm$ & $9.25 \pm$ & $155.0 \pm$ & $10.5 \pm$ & $4554.0 \pm$ & $204.0 \pm$ \\
ciliaris & 0.38 & 0.3 & 5.32 & 0.98 & 18.07 & 1.02 & 32.01 & 0.7 & 39.06 & 21.58 \\
\hline Eragrostis & $33.25 \pm$ & $7.25 \pm$ & $56.75 \pm$ & $8.0 \pm$ & $65.5 \pm$ & $7.0 \pm$ & $28.5 \pm$ & $7.25 \pm$ & $642.6 \pm$ & $313.2 \pm$ \\
japonica & 7.55 & 0.44 & 9.34 & 2.06 & 8.24 & 1.84 & 6.83 & 1.97 & 59.03 & 28.78 \\
\hline Eragrostis & $39.95 \pm$ & $6.75 \pm$ & $47.5 \pm$ & $6.25 \pm$ & $57.0 \pm$ & $5.5 \pm$ & $39.8 \pm$ & $6.25 \pm$ & $553.4 \pm$ & $316.7 \pm$ \\
nutans & 2.87 & 0.81 & 4.87 & 0.33 & 0.75 & 0.65 & 32.76 & 0.62 & 45.49 & 19.03 \\
\hline Eragrostis & $48.5 \pm$ & $7.5 \pm$ & $46.75 \pm$ & $13.0 \pm$ & $47.5 \pm$ & $12.5 \pm$ & $12.5 \pm$ & $6.0 \pm$ & 954.0 & $606.6 \pm$ \\
pilosa & 14.98 & 0.42 & 12.84 & 4.38 & 26.8 & 5.56 & 3.26 & 0.66 & \pm 56.42 & 47.48 \\
\hline Eragrostis & $56.0 \pm$ & $8.25 \pm$ & $43.5 \pm$ & $8.0 \pm$ & $60.5 \pm$ & $7.75 \pm$ & $16.0 \pm$ & $6.75 \pm$ & $720.0 \pm$ & $423.0 \pm$ \\
tenella & 23.98 & 2.67 & 9.47 & 0.39 & 22.76 & 14.47 & 3.86 & 0.84 & 69.83 & 25.76 \\
\hline Eragrostis & $67.0 \pm$ & $9.75 \pm$ & $78.75 \pm$ & $9.5 \pm$ & $73.75 \pm$ & $10.25 \pm$ & $57.75 \pm$ & $12.75 \pm$ & $1602.0 \pm$ & $1191.6 \pm$ \\
tremula & 19.04 & 2.58 & 9.34 & 0.34 & 25.97 & 2.65 & 12.75 & 2.64 & 48.38 & 64.47 \\
\hline Eragrostis & $48.5 \pm$ & $12.0 \pm$ & $58.75 \pm$ & $10.0 \pm$ & $55.75 \pm$ & $8.25 \pm$ & $12.25 \pm$ & $2.5 \pm$ & $1943.0 \pm$ & $837.0 \pm$ \\
unioloides & 8.37 & 1.89 & 11.98 & 0.97 & 14.87 & 1.86 & 2.40 & 0.076 & 48.34 & 49.23 \\
\hline Eragrostis & $45.0 \pm$ & $10.5 \pm$ & $47.0 \pm$ & $6.5 \pm$ & $40.75 \pm$ & $8.5 \pm$ & $10.25 \pm$ & $3.75 \pm$ & $1009.8 \pm$ & $644.4 \pm$ \\
viscosa & 2.09 & 2.56 & 25.42 & 0.12 & 28.87 & 2.15 & 1.74 & 0.64 & 49.76 & 34.48 \\
\hline
\end{tabular}

Table 2. Comparison of micromorphological characters of Palea

\begin{tabular}{|l|c|c|c|c|c|c|c|c|c|c|}
\hline \multirow{2}{*}{$\begin{array}{l}\text { Name of } \\
\text { species }\end{array}$} & \multicolumn{2}{|c|}{ Apex cells $(\boldsymbol{\mu m})$} & \multicolumn{2}{|c|}{ Middle cells $(\mu \mathrm{m})$} & \multicolumn{2}{|c|}{ Basal cells $(\mu \mathrm{m})$} & \multicolumn{2}{|c|}{ Hairs $(\boldsymbol{\mu m})$} & \multicolumn{2}{c|}{ Palea $(\boldsymbol{\mu m})$} \\
\cline { 2 - 13 } & Length & Width & Length & Width & Length & Width & Length & Width & Length & Width \\
\hline Eragrostis & $57.8 \pm$ & $11.4 \pm$ & $48.1 \pm$ & $10.9 \pm$ & $47.3 \pm$ & $9.8 \pm$ & $31.6 \pm$ & $8.6 \pm$ & $906.2 \pm$ & $585.9 \pm$ \\
cilianensis & 12.09 & 4.09 & 4.22 & 0.12 & 9.37 & 1.88 & 7.59 & 1.23 & 48.39 & 12.47 \\
\hline Eragrostis & $46.5 \pm$ & $12.75 \pm$ & $48.25 \pm$ & $11.0 \pm$ & $49.25 \pm$ & $12.0 \pm$ & $53.50 \pm$ & $17.0 \pm$ & $795.6 \pm$ & $392.4 \pm$ \\
ciliaris & 8.44 & 2.33 & 21.78 & 1.09 & 10.35 & 0.32 & 10.48 & 1.93 & 28.84 & 32.48 \\
\hline Eragrostis & $56.5 \pm$ & $8.25 \pm$ & $49.25 \pm$ & $9.75 \pm$ & $63.5 \pm$ & $7.75 \pm$ & $27.5 \pm$ & $5.75 \pm$ & $739.8 \pm$ & $360.0 \pm$ \\
japonica & 10.47 & 0.39 & 9.21 & 0.04 & 8.24 & 0.08 & 0.34 & 0.32 & 19.49 & 11.83 \\
\hline Eragrostis & $47.05 \pm$ & $7.0 \pm$ & $48.5 \pm$ & $4.75 \pm$ & $52 \pm$ & $6.25 \pm$ & $51.7 \pm$ & $6.5 \pm$ & $547.8 \pm$ & $369.5 \pm$ \\
nutans & 9.74 & 0.14 & 3.82 & 0.37 & 5.84 & 0.12 & 5.13 & 0.08 & 37.84 & 25.87 \\
\hline Eragrostis & $52.5 \pm$ & $7.75 \pm$ & $47.0 \pm$ & $12.0 \pm$ & $56.25 \pm$ & $9.75 \pm$ & $22.5 \pm$ & $6.0 \pm$ & $790.2 \pm$ & $340.2 \pm$ \\
pilosa & 14.37 & 0.07 & 11.98 & 1.33 & 10.47 & 2.37 & 3.19 & 0.49 & 38.39 & 17.84 \\
\hline Eragrostis & $53.75 \pm$ & $7.75 \pm$ & $53.0 \pm$ & $9.25 \pm$ & $45.25 \pm$ & $6.75 \pm$ & $26.00 \pm$ & $8.5 \pm$ & $993.0 \pm$ & $409.0 \pm$ \\
tenella & 13.03 & 0.12 & 11.34 & 0.32 & 9.54 & 1.83 & 8.54 & 0.74 & 37.40 & 54.35 \\
\hline Eragrostis & $42.75 \pm$ & $9.75 \pm$ & $49.5 \pm$ & $11.25 \pm$ & $51.0 \pm$ & $13.0 \pm$ & $38.75 \pm$ & $11.0 \pm$ & $1330.2 \pm$ & $750.6 \pm$ \\
tremula & 7.23 & 0.23 & 1.87 & 1.32 & 11.59 & 0.14 & 14.74 & 0.16 & 53.48 & 19.47 \\
\hline Eragrostis & $53.75 \pm$ & $15.5 \pm$ & $63.75 \pm$ & $15.35 \pm$ & $71.0 \pm$ & $10.75 \pm$ & $50.0 \pm$ & $9.0 \pm$ & $1740.0 \pm$ & $975.0 \pm$ \\
unioloides & 9.84 & 0.94 & 18.33 & 2.73 & 14.75 & 0.11 & 36.34 & 0.64 & 63.34 & 35.28 \\
\hline Eragrostis & $54.75 \pm$ & $11.0 \pm$ & $47.02 \pm$ & $10.5 \pm$ & $51.2 \pm$ & $6.5 \pm$ & $33.75 \pm$ & $5.0 \pm$ & $743.4 \pm$ & $430.0 \pm$ \\
viscosa & 12.48 & 0.78 & 12.78 & 0.13 & 3.37 & 0.05 & 2.49 & 0.95 & 23.48 & 27.32 \\
\hline
\end{tabular}

\section{Variation in undulation patterns}

By means of light microscopy the surface undulated patterns of epidermal long cell walls in the lemma and palea can be divided into two distinctly different types as observed in Setaria (Houyuan et al., 2009). The epidermal cell walls are having either $\Omega$ shaped undulation (undulation rounded, wider towards the apex and narrow at the base) or $\cap$ shaped undulation. Both these types further can produce branching sub ordinate types based on the degree of undulations as $\Omega$ I, II, III and $\cap$ I, II, III. The depth and width of the undulations vary in the different studied species depending on which in some the undulations appear very compact, while in some it is scare as seen very distinctly in the lemma of E. viscosa and E. ciliaris. All types of undulations seen in Figure 7.

$\cap$ shaped undulation in the palea is very prominent in E. pilosa. In the apex and basal region, the undulation is more or less same. It does not become narrow at the base. 
This variation observed suggested that the surface undulated patterns of epidermal long cell walls in the lemma and palea can be used to distinguish the different species.

Houyuan et al. (2009) divides the ending structures of epidermal long cell into cross wavy type and cross finger type based on characteristics of the dendriform epidermal long cell endings joining others. The average width of endings interdigitation of dendriform epidermal long cells is about $4.37 \pm 0.89 \mu \mathrm{m}(\mathrm{N}=2774)$ in cross wavy pattern and in cross finger type, dendriform epidermal long cell endings join others in a deeply digital pattern with average width of the endings interdigitation of dendriform epidermal cells to be longer $(8.95 \pm 2.02$ $\mu \mathrm{m}, \mathrm{N}=3303$ ).

Epidermal long cell walls are $\Omega$ undulated (undulations rounded, wider toward the apex and narrower at the base) or $\eta$ undulated. Both these can produce branching subordinate types based on the degree of undulations as $\Omega$ I, $\Omega$ II, $\Omega$ III.

This study shows that species of Eragrostis vary in features of spikelet (number, length and degree of overlap), features of glumes (length relative to the upper and lower glume and relative to spikelet length, shapes and apex), number of florets, number of anthers features of lemma and palea (shape, length, width and micromorphology), features of lemmatal awns (length relative to lemma and number), shape of the apex of the distal cell in the microhair. All the variable reproductive morphological characters of the taxa studied are potentially taxonomically informative. palea:

A diagnostic key is prepared based on morphological and micromorphological characters of lemma and

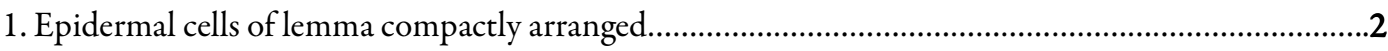

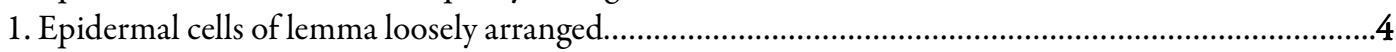

2. Middle region of lemma epidermal cells do not show specific pattern of undulation...............E. pilosa

2. Middle region of lemma epidermal cells shows $\Omega$ shaped undulation.................................................

3. Apex region of lemma epidermal cells shows $\bigcap$ shaped undulation.......................................E. nutans

3.Apex region of lemma epidermal cells shows wavy undulation with less compactly folding... $E$. viscosa

4. Basal region of palea epidermal cells shows $\Omega$ shaped undulation.....................................................

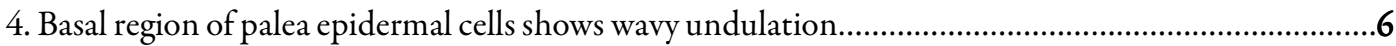

5. Middle region of lemma epidermal cells shows $\Omega$ shaped undulation..................................E. japonica

5. Middle region of lemma epidermal cells shows wavy undulation...........................................E. tremula

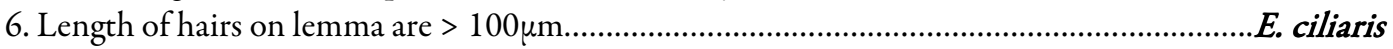

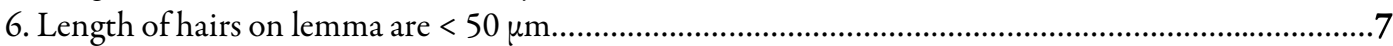

7. Short cells in basal region of lemma are lesser in number.................................................. unioloides

7. Short cells in basal region of lemma are more in number...................................................................

8. Apex region of palea epidermal cells shows $\cap$ shaped undulation...................................E. cilianensis

8. Apex region of palea epidermal cells shows irregular undulation.............................................. tenella

\section{Conclusions}

Except E. nutans all the other species are annuals. The culm in E. tenella and E. unioloides is strictly geniculating ascending while in $E$. nutans, $E$. viscosa, E. japonica and $E$. ciliaris it is erect. In $E$. cilianensis, $E$. Pilosa and E. tremula it is erect or geniculating ascending. Inflorescence or spikelets in all the species are dorsiventrally compressed except in E. ciliaris. Spikelets of E. pilosa, E. tremula and E. unioloides are prominently laterally compressed while spikelets of E. japonica, E. nutans, E. cilianensis, E. ciliaris, E. viscosa and $E$. tenella are not compressed. The length and breadth of the spikelet is maximum in E. tremula with maximum number of florets (12-36). Spikelets of E. nutans invariably has 1 or 2 florets. (Gandhi et al., 2016). 
The size of the cells at the apex, middle and base of the lemma varied in a species within the length and width. The length of the lemma was maximum in E. tremula and E. unioloides while it was minimum in $E$. japonica and E. nutans.

Similarly, size of the cells showed variation in the three different regions (apex, middle and basal) of the pale of the species and within species. The size of palea was maximum in E. unioloides and minimum in $E$. nutans. There was a significant variation in the characteristic features of microhairs.

One of the main problems with micromorphological studies is to determine the optimal site of observation. The lemma shows variations in the expression of micromorphological characters within its apex, base and margins, whereas the palea varies mostly near the apex and in some cases in the wings.

The analysis of the epidermal micromorhology of lemma and palea reveals considerable variation in the nine species of Eragrostis. These characters are valuable for systematic studies in Poaceae.

Based on the different micromorphological variation observed in the lemma and palea diagnostic key has been prepared which would facilitate in the identification of the different species.

\section{Authors' Contributions}

Both authors read and approved the final manuscript.

\section{Acknowledgements}

Authors are thankful to Mayuri Chaudhri for the technical support provided.

\section{Conflict of Interests}

The authors declare that there are no conflicts of interest related to this article.

\section{References}

Amarasinghe V, Watson L (1990). Taxonomic significance of microhair morphology in the genus Eragrostis Beauv. (Poaceae). Taxon 39:59-65. https://doi.org/10.2307/1223180

Baum BR, Estes JR, Gupta PK (1987). Assessment of the genomic system of classification in the Triticeae. American Journal of Botany 74:1338-1395. https://doi.org/10.1002/j.1537-2197.1987.tb08753.x

Clayton WD, Renvoize SA (1986). Genera Graminum. Grasses of the World. Royal Botanical Garden, Kew.

Clayton WD, Vorontsova MS, Harman KT, Williamson H (2006 onwards). Tripogon, GrassBase - The Online World Grass Flora. Retrieved 2013 September 9 from http://www.kew.org/data/grasses-db.html.

Clayton WD, Phillips SM, Renvoize SA (1974). Gramineae (part 2). In Polhill RM (Ed). Flora of Tropical East Africa. pp 177-450.

Gandhi D, Albert S, Pandya N (2016). Handbook on the morphology of common grasses: Identification and characterization of caryopses and seedlings. CRC Press.

Ellis RP (1979). A procedure for standardizing comparative leaf anatomy in the Poaceae. II. The epidermis as seen in surface view. Bothalia 12:641-671. https://doi.org/10.4102/abc.v12i4.1441

Houyuan L, Naiqin W, Baozhu L (1997). Recognition of rice phytoliths, in the state of the art of phytoliths in soils and plants. Pinalla A, Juan-Tresserras J, Machado MJ (Eds). Monografias del Centro de Ciencias Medioambientales. Madrid: Consejo Superior de Investigaciones Cientificas pp 59-174.

Johnston CR, Watson L (1976). Microhairs: a universal characteristic of non festucoid grass genera? Phytomorphology 26:297-301. 
Karthikeyan S, Jain SK, Nayar MP, Sanjappa M (1989). Poaceae. In: Florae Indicae Enumeratio Monocotyledonae. Botanical Survey of India, Calcutta.

Metcalfe CR (1960). Anatomy of the monocotyledons. 1. Gramineae. Oxford: Clarendon Press.

Peterson PM, Boechat SC (2001). Eragrostis. In: Peterson PM, Soreng RJ, Davidse G, Filgueiras TS, Zuloaga FO, Judziewicz EJ (Eds). Catalogue of New World grasses (Poaceae: Chloridoideae). Contr. U.S. Natl. Herb. Pp 41:1255.

Peterson PM, Duvall MR, Christensen AH (1993). Allozyme differentiation among Bealia mexicana, Muhlenbergia argentea and M. lucida (Poaceae: Eragrostideae). Madroiio 40:148-160.

POWO (2021). Plants of the World Online. Facilitated by the Royal Botanic Gardens, Kew. Published on the Internet. http://www.plantsoftheworldonline.org/

Prat H (1932). L'epiderme des Graminées. Ètudeanatomique et systematique. Annales des sciences naturelles. Botanique 10(14):117-324.

Prat H (1936). La Sistématique des Graminées. Annales des sciences naturelles. Botanique 10(18):165-257.

Scholz H, König P (1985). Ergänzungenzur Flora Saudi-Arabiens: Gramineae. Willdenowia 14:373-377. https://www.jstor.org/stable/3996251

Shah GL (1978). Flora of Gujarat State. Vol. II. Sardar Patel University: Vidhyanagar.

Simon BK, Alfonso Y (2011). Tripogon. AusGrass2. Retrieved 2014 June 20 from http://ausgrass2.myspecies.info/.

Tateoka T, Inoue S, Kawano S (1959). Notes on some grasses IX: Systematic significance of bicellular microhairs of leaf epidermis. Botanical Gazette 121:80-91. https://doi.org/10.1086/336048

Tateoka T (1967). Notes on some grasses XIX. Systematic significance of microhairs of lodicule epidermis. Botanical Magazine (Tokyo) 80:394-403. https://doi.org/10.15281/jplantres1887.80.394

Terrell EE, Wergin WP (1981). Epidermal features and silica deposition in Lemmas and awns of Zizania (Gramineae). American Journal of Botany 68(5):697-707. https://doi.org/10.1002/j.1537-2197.1981.tb12402.x

Van DenBorre A, Watson L (1994). The infrageneric classification of Eragrostis (Poaceae). Taxon 43:383-422. https://doi.org/10.2307/1222716

Watson L, Dallwitz MJ (1992). The grass genera of the world. CAB International, Wallingford, Oxford, UK.

Watson L, Clifford HT, Dallwitz MJ (1985). The classification of Poaceae: Subfamilies and supertribes. Australian Journal of Botany 33:433-484. https://doi.org/10.1071/BT9850433

Zeid M, Echenique V, Díaz M, Pessino S, Sorrells ME (2010). Eragrostis. Wild Crop Relatives: Genomic and Breeding Resources 135-151. https://doi.org/10.1007/978-3-642-14255-0_8

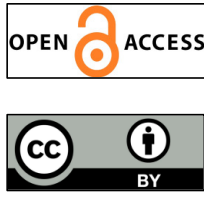

The journal offers free, immediate, and unrestricted access to peer-reviewed research and scholarly work. Users are allowed to read, download, copy, distribute, print, search, or link to the full texts of the articles, or use them for any other lawful purpose, without asking prior permission from the publisher or the author.

License - Articles published in Notulae Scientia Biologicae are Open-Access, distributed under the terms and conditions of the Creative Commons Attribution (CC BY 4.0) License.

(c) Articles by the authors; SHST, Cluj-Napoca, Romania. The journal allows the author(s) to hold the copyright/to retain publishing rights without restriction. 